UDC 378.091

DOI https://doi.org/10.31470/2415-3729-2021-13-96-109

\title{
Forms Organization of Work With People With Special Educational Needs in China
}

\section{Zeng Guanghai,}

Postgraduate,

H.S. Skovoroda Kharkiv National Pedagogical University,

$\triangle$ 2, Valentynivska Str., Kharkiv, Ukraine, 61022

E-mail: 937732545@qq.com

ORCID: https://orcid.org/0000-0003-1262-1512

Date of receipt of the article: April 16, 2021

Article accepted for publication: June 02, 2021

\section{Форми організація роботи 3 людьми 3 особливими освітніми потребами в Китаї}

\section{Цзен Гуанхай}

аспірант,

Харківський національний педагогічний університет імені Г.С. Сковороди

вул. Валентинівська 2, Харків, Україна, 61022

Дата надходження статті: 16 квітня 2021 p. Стаття прийнята до друку: 02 червня 2021 р.

\section{Absract}

The article analyzes the conditions for providing accessible education for people with special educational needs in China. The development of inclusive education, its position at this stage of education in China is considered. The aim of the article is to reveal the essence of the concept of «inclusive education» and to define the forms of organizing the work of people with special educational needs in China. To achieve the goal of the study, the following research methods have been used: analysis of scientific literature, observation, system analysis, comparative analysis, logical analysis, analogy, methods of 
classification, systematization, generalization, analysis of personal experience of teaching and learning in higher educational institutions in China, comparison and interpretation of the obtained data. The results. The author defines that inclusive education is the provision of equal access to education for all students, taking into account the diversity of educational needs and individual capabilities of the individual. Based on the analysis of the scientific literature, it is shown that effective forms of organizing the educational process of children with special needs are: education in a general (inclusive) classroom, if necessary, with individual or group support; training in a correctional class of a general secondary education institution under the guidance of a special teacher, with participation in general school activities; distance learning for students who are physically unable to attend educational institutions; training in a medical and social institution, in particular with partial inclusion in a general secondary education institution. The article proves that inclusion is not a form, but a new education with its humanistic philosophy of possibilities and free choice, it is a necessary preparation for life and full integration of everyone into society. Conclusions. The author is convinced that the effectiveness of inclusive education depends on five main organizational and pedagogical conditions: the availability of an accessible environment and humane relations with all participants in the educational process; scientifically based system of integration of children into mixed (inclusive) groups; high professionalism of teachers and leaders; acceptance of each student and involvement, organizational culture and spirit of mutual understanding; integration of an inclusive educational organization with social institutions.

Key words: inclusive education, educational process, people with special educational needs, forms of work, organization, China.

\section{References}

1. Huang Zhicheng, Zhong Jianwei. (2002). The rationale for inclusive education: an analysis of three dimensions. Foreign Education Research, 11.

2. Wang Peifeng, Yu Bingxia. (2002). Educational equity is the core connotation of inclusive education. China Special Education, 03.

3. Yuan Tingting. (2002) China's inclusive education: starting from the establishment of a comprehensive concept. Hefei Union University Journal, 02. 
4. Liu Lili. (2002). A Comparative Study on Several Issues of Inclusive Education. Journal of Mudanjiang Teachers College (Philosophy and Social Sciences Edition), 01.

5. Zhong Jianwei. (2002). Fairness and Equality: The Archimedes Pivot to Support the Development of Inclusive Education. Global Education Outlook, 05.

6. Deng Meng, Pan Jianfang. (2003). Some theoretical reviews on inclusive education and their enlightenment to us. China Special Education, 04.

7. Kong Ming. (2003). Inclusive education and its psychological dilemma. China Special Education,06.

8. Liu Hao. (2003). The role of educational resources in the community in promoting inclusive education. China Special Education, 06.

9. Sun Weixia. (2003). Inclusive Education: Concept and Implementation. Coal Higher Education, 03.

10. Wang Peifeng. (2003). Ding Bingxia. Educational Equity: An Interpretation of the Connotation of Inclusive Education. Modern Special Education, 02.

11. Li Yisheng, Cai Jun. (2003). Inclusive education: the integration of children with special needs in ordinary schools. Modern Special Education, 05.

12. Zhong Jianwei. (2003). Inclusive Education: Definition and Ideas. Global Education Outlook, 05.

\section{Вступ}

Розвиток інклюзивної освіти нині є актуальною проблемою та життєвою необхідністю в Китаї, оскільки розуміння суті поняття «інклюзія» пронизане духовним та психологічним змістом освіти та пов'язано з аксіологічними (гуманістичними, ціннісними, культурними) аспектами життя.

Інклюзивна освіта - це забезпечення рівного доступу до освіти для всіх здобувачів освіти з урахуванням різноманітності освітніх потреб та індивідуальних можливостей особистості (Ван Пейфен, Дін Бінся, 2002). Це поняття, яке широко транслюється для опису процесів та результатів навчання та виховання людей $з$ особливими потребами у закладах освіти. Ця освіта спрямована на пошуки 
розв'язання проблем та подолання бар'єрів в отриманні доступної якісної освіти кожного здобувача з особливостями розвитку, що лежить у сфері духовно-моральних дилем всіх цивілізацій i, що особливо значущо, - для багатотисячолітньої духовної практики та моралі китайського народу.

У Китаї нині набуває актуальності, інтенсивно розвиваючись, система інклюзивної освіти як важлива складова усієї стратегії галузі освіти. Озираючись на успіхи розвитку інклюзії у сусідніх країнах насамперед i, переймаючи світовий досвід освіти, китайський уряд вносить величезний внесок у розвиток цього напряму. Слід зазначити, що процеси модернізації інклюзивної освіти, характерні як для України, так і для Китаю, мають одне з важливих завдань індивідуалізації навчання. Це передбачає не тільки відхід від уніфікації у навчанні людей з особливими освітніми потребами на всіх рівнях, а також впровадження в систему інклюзивної освіти інноваційних методів навчання та форм роботи, а також глибоке осмислення методологічних та дидактичних основ процесу навчання людей з особливими освітніми потребами.

Важливе значення у цьому плані має аналіз наукової літератури 3 цієї проблеми (Хуан Чжичен, Чжун Цзяньвей, 2002; Ден Мен, Пан Цзяньфан, 2003; Ван Пейфен; Дін Бінся, 2003), концептуальних основ (Ван Пейфен, Ю Бінся, 2002; Конг Мін, 2003; Чжун Цзяньвей, 2003) та особливостей організації процесу навчання в інклюзивному просторі (Юань Тінтін, 2002), виявлення проблем у системі інклюзивної освіти (Лю Лілі, 2002; Лю Хао, 2003), спільних для різних країн, та обгрунтування способів вирішення цих проблем (Чжун Цзяньвей, 2002; Сунь Вейся, 2003; Лі Ішен; Цай Цзюнь, 2003). Разом 3 тим, актуальність означеної проблеми постійно зростає, оскільки нерозкритими залишаються форми організації роботи людей з особливими освітніми потребами.

Мета статті - на основі проведеного аналізу наукової літератури розкрити суть поняття «інклюзивна освіта» та визначити форми організації роботи людей з особливими освітніми потребами в КНР.

\section{Матеріал і методи дослідження}

Для досягнення мети дослідження були використані такі методи дослідження: аналіз наукової літератури, спостереження, що 
дозволили визначити ступінь актуальності проблеми; аналіз концептуальних положень та висновків, що містяться у філософській, педагогічній та методичній літературі; системний аналіз, порівняльний аналіз, метод класифікації, методи систематизації, узагальнення, логічного аналізу, аналогії, аналіз особистого досвіду навчання та викладання в ЗВО КНР, порівняння та інтерпретація одержаних даних.

\section{Результати та їх обговорення}

Посилаючись на проведений науковий аналіз дослідження китайського вченого Лі Ішен (2003), ефективність інклюзивної освіти залежить від п'яти основних організаційно-педагогічних умов: наявності доступного середовища та гуманних взаємин 3 усіма учасниками освітнього процесу; науково-обгрунтованої системи інтеграції дітей до змішаних (інклюзивних) груп; високого професіоналізму педагогів та керівників; прийняття кожного учня та залученості, організаційної культури та духу взаєморозуміння; інтеграції інклюзивної освітньої організації 3 соціальними інститутами (Лі Ішен, 2003).

Щодо інтеграції дітей, китайський учений Чжун Цзяньвей (2003) переконливо доводить про необхідність створення системи включення дитини 3 особливими освітніми потребами в суспільство. Вчений зазначав, що будь-яка корекційна школа, «замикає свого вихованця у вузьке коло специфічного шкільного колективу, створює замкнутий світ, у якому все пристосовано до дефекту дитини, все фіксує іiі увагу на своєму недоліку і не вводить у справжнє життя» (Чжун Цзяньвей, 2003).

На переконання дослідника Юань Тінтін (2002), китайська система освіти має взяти за основу організацію інклюзивної освіти, прийняту у Франції. Дана система освіти має на меті такі форми організації освітнього процесу з дітьми з особливими потребами:

1. Навчання у загальноосвітньому (інклюзивному) класі, за необхідності з індивідуальним чи груповим супроводом.

2. Навчання у корекційному класі закладу загальної середньої освіти під керівництвом спеціального педагога, за участю у загальношкільних заходах.

3. Дистанційне навчання для учнів, які фізично що неспроможні відвідувати заклади освіти. 
4. Навчання в медико-соціальній установі, зокрема із частковою інклюзією до закладу загальної середньої освіти (Юань Тінтін, 2002).

Як позитивне, відмітимо про ухвалення «Закону КНР про обов'язкове навчання» (1986). Широкого поширення та розвиток інклюзивна освіта здобула після прийняття у 1994 р. в Іспанії Саламанської декларації на Всесвітній конференції людей з особливими потребами, проведеної ЮНЕСКО та закріпила принципи інклюзивного навчання. Це послужило початком вивчення та впровадження методик роботи з особливими дітьми на офіційному рівні та отримало підтримку китайського уряду у реалізації програми.

Державний комітет 3 освіти надав правила проведення спільного навчання:

1. Діти з обмеженими можливостями, що беруть участь у програмах спільного навчання, повинні відвідувати школу за місцем проживання (або поблизу).

2. Вік вступ до школи зі спільним навчанням дітей з обмеженими можливостями та звичайних дітей має бути однаковим. В особливих випадках можливе розширення віку.

3. Кількість дітей з обмеженими можливостями у звичайних школах у класах з спільним навчанням має бути 1-2 особи, не більше 3 осіб.

4. Звичайні школи повинні, відповідно до законодавства, надавати освітні послуги дітям з обмеженими можливостями. Школи не мають права відмовляти в освітніх послугах дітям з особливими потребами».

У березні 1999 р. було прийнято 9-й п'ятирічний план економічного та соціального розвитку Китаю та перспективна програма розвитку до 2010 року, які згодом були доповнені програмами розвитку до 2020 року, 2030 та 2050 років.

У 1999 р. підвищення якості освіти увійшло до переліку важливих цілей Китаю, що дозволило покращити зміст освітніх програм. У 2001 році почалася реформа щодо обов'язкових предметів, що входять до освітньої програми.

3 моменту початку політики реформ та відкритості, у Китаї була сформована система спеціальної освіти. 
У березні 2011 р. 4-та сесія Всекитайських зборів народних представників 11-го скликання прийняла 12-й п'ятирічний план, згідно з яким в основі економічного розвитку лежить пріоритетність освіти. Виконання п’ятирічки у галузі освіти є лише кроком на шляху реалізації «Державного плану реформи та розвитку утворення КНР на середньостроковий та довгостроковий період.

Нині, на основі затверджених нормативних документів, для початкової та неповної середньої школи пропонуються нові освітні стандарти з 14 предметів (не рахуючи факультативів): мова та література, математика, наука (3-6 класи та 7-9 класи); фізика, хімія, біологія, географія, історія, історія та суспільство, іноземна мова (англійська, японська), музика, малювання, мистецтво, фізкультура та здоров'я.

Відмітимо той факт, що стандарти для кожного предмета визначені відповідно до трьох критеріїв (знання та навички, процес та методи, емоційно-ціннісні орієнтації). Все це призвело до значущих змін.

На етапі розвитку китайської спеціальної освіти, в країні налічується близько 1767 спеціальних шкіл. Такі дані надає Міністерство освіти Китаю. Їх недостатньо. Ці школи мають підготовлених педагогів та добре фінансуються. Але спеціальні школи мають і багато недоліків. Навчальна програма там обмежена, та потрапивши в систему спеціальної освіти, $є$ ризик відсутності можливості повернутися до звичайної школи, не кажучи вже про вищу освіту.

У будь-якій навчальній програмі спеціальної освіти сказано: індивідуальний підхід, облік індивідуальних потреб у колективному навчанні, індивідуальне консультування, партнерське навчання, ступінчасте навчання та інші методи викладання сприяють розвитку учнів 3 особливими потребами, консультування викладачів та вчителів з усіх предметів у тісній координації на основі індивідуальних планів навчання.

Спеціальні школи Китаю знаходяться в містах. Вони важкодоступні для дітей з особливими освітніми потребами із сіл, а там мешкає 75\% таких дітей Китаю. Крім того, такі школи можуть спеціалізуватися на одному виді інвалідності, наприклад, на глухоті. 
Більш краща ситуація з організацією освітнього процесу дітей, які страждають захворюваннями органів зору чи слуху. Спецшколи такого роду існують у Китаї доволі давно. Утім, шкіл для таких дітей шкіл катастрофічно не вистачає.

Спеціальні школи, де викладачі опанували методику спілкування та освіти, наприклад, тих же дітей-аутистів, є лише в великих містах Китаю. Але й у ці школи діти досить часто потрапляють лише тому, що їм складно вчитися з однолітками за стандартною програмою.

Водночас необхідно надавати методичну підтримку в галузі спеціальної освіти батькам та звичайним вчителям.

На переконання Ван Пейфен, Ю Бінся (2002), звичайні школи повинні, відповідно до законодавства, надавати освітні послуги дітям 3 обмеженими можливостями. Школи не мають права відмовляти в освітніх послугах дітям з особливими потребами. У зазначених документах детально розглядаються проблеми освіти осіб з обмеженими можливостями.

У Китаї питання залучення дітей з особливими освітніми потребами до соціального життя активно обговорюється упродовж багатьох років у межах дискусій про загальну реформу освіти. Конституція та законодавство країни гарантують усім дітям рівний доступ до отримання базової освіти у державних та приватних школах.

Люди 3 обмеженими можливостями не виключаються iз загальної системи освіти за ознакою інвалідності. Ця вимога поширюється на всі рівні освіти: початкова, середня, вища та професійна підготовка.

Однак, у Китаї високий рівень неписьменності серед осіб з обмеженими можливостями.

У Китаї більшість дітей з порушеннями здоров'я не відвідують школу. У здебільшого населення живе у сільській місцевості, та у дітей обмежений доступ до школи. І тільки у великих містах є діти, які відвідують спеціальні школи для дітей з особливими освітніми потребами.

Але, незважаючи на те, що швидко змінюється картина світу, iii соціокультурне середовище та, загалом, вся освітня система, нині залишаються невирішеними бажані проблеми, цілі та завдання інклюзивної освіти у Китаї, такі як-от: 
- недостатня підготовленість фахівців: психологів, педагогів та управлінців до здійснення інклюзивної освіти;

- труднощі, що виникають у комунікаційній, інформаційноцифровій культурі, теоретико-методичному, організаційноосвітньому, соціально-економічному, особистісно-психологічному та професійно-ідеологічному рівнях;

- досвід викладання та управління інклюзивною освітою знаходиться на початковому етапі досліджень та практики;

- немає програм, націлених на полегшення адаптації осіб з особливими освітніми потребами, що збільшить можливість згуртування людей та соціальну стабільність у суспільстві;

- слабка система психолого-педагогічної підтримки та тьюторського супроводу;

- відсутні технології організаційного залучення батьків до соціально-освітнього процесу тощо;

- декларація рівності людей, їх прав та обов'язків часто суперечать реалізації в житті;

- досі не сформовано національну правову базу для людей з особливими освітніми потребами як повноцінних вільних громадян;

- немає у суспільстві системної практики толерантності, яка допоможе вирішити завдання соціальної активності, зняття негативного ставлення та подолання ізоляції людей з особливими потребами;

- спостерігається недостатнє формування освітніх та реабілітаційних інфраструктур, що вводять у процес інтегрованого навчання; швидше, як і раніше, використовуються індивідуальна та інтернована форми навчання;

- суспільством не до кінця усвідомлені морально-психологічні корені інвалідизації як непродуктивних дій самої сім’ї та особистісного вибору людини щодо лікування, навчання та розвитку в соціумі, інтенсивного громадського стресу;

- визначається великий розрив у методах навчання та викладання дисциплін; навчальні курси не синхронізовані під необхідні потреби осіб з особливими освітніми потребами, що призводить до неякісного сприйняття ними знань;

- в освітніх установах на всіх рівнях недостатнє оснащення ресурсним обладнанням, а в інформаційно-технологічному (цифровому) суспільстві володіння та розвиток цифрової культури стає 
вкрай важливим і перспективним напрямом для осіб із особливими освітніми потребами.

Поряд із зазначеними проблемами, доцільною $є$ розробка форм, упровадження яких в освітній процес дітей з особливими освітніми потребами буде ефективною:

- необхідно надавати допомогу учням та, тим самим, знижувати їх психологічне навантаження;

- створювати та вдосконалювати способи індивідуального догляду;

- зміцнювати почуття поваги та рівності;

- сприяти інклюзивному культурному становленню освіти у галузі психічного здоров'я тощо, щоб здорові учні звертали увагу на почуття та потреби дітей з особливими потребами.

У зв'язку з цим необхідно розуміти особливе значення активного просування інклюзивної культури та розширювати простір для інтеграції здобувачів освіти з особливими потребами.

\section{Висновки}

Отже, вирішення зазначених проблем, цілей та завдань дозволить забезпечити реалізацію основних положень інклюзивної освіти, основою якої є людська гуманність. У людей з особливими освітніми потребами з'явиться більше шансів на визнання їхнього існування, підтвердження важливості їх різних сторін буття, бути почутими та стати повноправними членами суспільства. Адже інклюзія - це не форма, а нова освіта зі своєю гуманістичною філософією можливостей та вільного вибору, це необхідна підготовка до життя та повноцінної інтеграції кожного в суспільство.

На основі проведеного аналізу наукової літератури зазначимо, що дієвими формами організації освітнього процесу дітей 3 особливими потребами $\epsilon$ : навчання у загальноосвітньому (інклюзивному) класі, за необхідності з індивідуальним чи груповим супроводом; навчання у корекційному класі закладу загальної середньої освіти під керівництвом спеціального педагога, за участю у загальношкільних заходах; дистанційне навчання для учнів, які фізично що неспроможні відвідувати заклади освіти; навчання в медико-соціальній установі, зокрема із частковою інклюзією до закладу загальної середньої освіти. 
Перспективи подальших розвідок вбачаємо в реалізації визначених форм організації освітнього процесу дітей з особливими потребами в українські заклади освіти.

\section{Література}

1. 黄志成, 仲建维. 全纳教育的理据:三个纬度的分析 [J]; 外国教 育研究;2002年11期.

2. 王培峰, 于炳霞. 教育公平是全纳教育的核心内涵[J]; 中国特 殊教育;2002年03期.

3. 袁婷婷.中国的全纳教育: 从树立全面的理念做起 [J]; 合肥联 合大学学报;2002年02期.

4. 刘莉莉. 全纳教育若干问题的比较研究[J]; 牡丹江师范学院学 报(哲学社会科学版);2002年01期.

5. 仲建维.公正和平等:支撑全纳教育发展的阿基米德支点 [J]; 全球教育展望;2002年05期.

6. 邓猛,潘剑芳.爸于全纳教育思想的几点理论回顾及其对我们 的启示[J]; 中国特殊教育;2003年04期.

7. 孔明. 全纳教育及其心理学困境[J]; 中国特殊教育;2003年06 期.

8. 刘昊.社区中的教育资源对于推行全纳教育的作用[J]; 中国特 殊教育;2003年06期.

9. 孙伟霞.全纳教育:理念与实施 [J];煤炭高等教育;2003年03 期.

10. 王培峰.丁炳霞; ; 教育公平: 对全纳教育内涵的一种解读 [ J]; 现代特殊教育;2003年02期.

11. 李义胜.蔡俊;, 全纳教育:普通学校对特殊儿童的融合 [J];现 代特殊教育; 2003年05期. 期.

12. 仲建维. 全纳教育:定义与理念 [J]; 全球教育展望;2003年05

\section{Цзен Гуанхай}

\section{Форми організація роботи 3 людьми 3 особливими освітніми потребами в Китаї}

\section{Анотація}

У статті аналізуються умови надання доступної освіти для людей 3 особливими освітніми потребами в Китаї. 
Розглядається питання розвитку інклюзивної освіти, її становище на даному етапі розвитку освіти в Китаї. Метою статті $\epsilon$ розкриття суті поняття «інклюзивна освіта» та визначення форм організації роботи людей з особливими освітніми потребами в КНР. Автором визначено, що інклюзивна освіта - це забезпечення рівного доступу до освіти для всіх здобувачів освіти 3 урахуванням різноманітності освітніх потреб та індивідуальних можливостей особистості. На основі проведеного аналізу наукової літератури показано, що дієвими формами організації освітнього процесу дітей 3 особливими потребами є: навчання у загальноосвітньому (інклюзивному) класі, за необхідності з індивідуальним чи груповим супроводом; навчання у корекційному класі закладу загальної середньої освіти під керівництвом спеціального педагога, за участю у загальношкільних заходах; дистанційне навчання для учнів, які фізично що неспроможні відвідувати заклади освіти; навчання в медико-соціальній установі, зокрема із частковою інклюзією до закладу загальної середньої освіти. В статті доведено, що інклюзія - це не форма, а нова освіта зі своєю гуманістичною філософією можливостей та вільного вибору, це необхідна підготовка до життя та повноцінної інтеграції кожного в суспільство. Автор переконаний, що ефективність інклюзивної освіти залежить від п'яти основних організаційно-педагогічних умов: наявності доступного середовища та гуманних взаємин з усіма учасниками освітнього процесу; науково-обгрунтованої системи інтеграції дітей до змішаних (інклюзивних) груп; високого професіоналізму педагогів та керівників; прийняття кожного учня та залученості, організаційної культури та духу взаєморозуміння; інтеграції інклюзивної освітньої організації з соціальними інститутами.

Ключові слова: інклюзивна освіта, освітній процес, люди 3 особливими освітніми потребами, форми роботи, організація, Китай. 


\section{Цзен Гуанхай}

\section{Формы организация работы с людьми с особенными об- разовательными потребностями в Китае}

\section{Аннотация}

В статье проанализировано условия предоставления доступного образования людям с особыми образовательными потребностями в Китае. Рассматривается вопрос развития инклюзивного образования, его положение на данном этапе развития образования в Китае. Целью статьи является раскрытие сущности понятия инклюзивное образование и определение форм организации работы людей с особыми образовательными потребностями в Китае. Автором определено, что инклюзивное образование - это обеспечение равного доступа к образованию для всех соискателей с учетом разнообразия образовательных потребностей и индивидуальных возможностей личности. На основе проведенного анализа научной литературы показано, что действенными формами организации образовательного процесса детей с особыми потребностями являются: обучение в общеобразовательном (инклюзивном) классе при необходимости с индивидуальным или групповым сопровождением; обучение в коррекционном классе заведения общего среднего образования под руководством специального педагога, с участием в общешкольных мероприятиях; дистанционное обучение для учащихся, физически не способных посещать учебные заведения; обучение в медико-социальном учреждении. В статье доказано, что инклюзия - это не форма, а новое образование со своей гуманистической философией возможностей и свободного выбора, необходимая подготовка к жизни и полноценной интеграции каждого в общество. Автор убежден, что эффективность инклюзивного образования зависит от пяти основных организационно-педагогических условий: наличия доступной среды и гуманных отношений со всеми участниками образовательного процесса; научно-обоснованной системы интеграции детей в смешанные (инклюзивные) группы; высокого профессионализма педагогов; принятие каждого ученика и вовлечённости, организационной культуры и духа взаимопонима- 
ния; интеграции инклюзивной образовательной организации с социальными институтами.

Ключевые слова: инклюзивное образование, образовательный процесс, люди с особыми образовательными потребностями, форма работы, организация, Китай. 